\title{
THE EFFECT OF NUSA NATIONAL BANK SERVICE QUALITY ON CUSTOMER LOYALTY
}

\section{PENGARUH KUALITAS PELAYANAN BANK NUSA NASIONAL TERHADAP LOYALITAS NASABAH}

\author{
Dennis Rydarto Tambunan \\ ${ }^{1}$ Fakultas Ekonomi Universitas Dehasen Bengkulu \\ Coresponding author : tambunandennis376@gmail.com
}

How to Cite :

Tambunan, Dennis Rydarto. The Effect Of Nusa National Bank Service Quality On Customer Loyalty. Bima Journal: Bussines Managemet and Accounting. DOI:https://doi.org/10.37638/bima.1.2.84-95

\section{ARTICLE HISTORY} Received [XX Month $X x x x]$ Revised [xx Month $x x x x]$ Accepted [xx Month $x x x x]$

\section{KEYWORDS}

customer's quality influence; customer's loyality

This is an open access article under the $C C-B Y-S A$ license

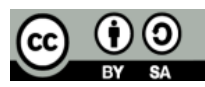

\section{ABSTRAK}

Mengukur kualitas pelayanan serta pengaruh kualitas pelayanan (service quality) itu sendiri terhadap loyalitas nasabah di Bank Nusa. Segmen nasabah yang diteliti adalah nasabah deposito, tabungan dan giro, karena pada saat sekarang banyak penawaran dari Bank-bank pesaing yang menawarkan produk yang serupa dan seberapa jauh customer dapat menentukan pilihannya. Penelitian dilakukan dengan menggunakan metode survai, dengan tujuan untuk mengetahui tanggapan atau pendapat dari sebagian populasi yang bersangkutan terhadap objek penelitian. Melalui penelitian ini diharapkan dapat dijadikan sebagai dasar dan bahan evaluasi bagi pihak Bank Nusa Nasional dalam rangka meningkatkan loyalitas nasabah melalui kualitas pelayanan. Tanggapan responden terhadap kualitas pelayanan Bank BNN yang meliputi tangibles, emphaty, reliability, responsiveness, dan assurances pada umumnya relatif mendapat penilaian baik dari para nasabahnya. Tingkat kesesuaian antara harapan nasabah dan kualitas pelayanan Bank BNN secara keseluruhan relatif tinggi. Sedangkan Loyalitas nasabah cenderung belum terlalu tinggi. Dari hasil pengujian statistik ternyata bahwa kualitas pelayanan Bank BNN berpengaruh cukup tinggi terhadap loyalitas para nasabahnya. Dalam upaya meningkatkan loyalitas nasabah melalui kualitas pelayanan Bank, maka Bank Nusa Nasional Cabang Bandung perlu mempertahankan dan meningkatkan kualitas pelayanannya diantaranya melalui memperluas jaringan pelayanan meningkatkan keterampilan petugas customer services, melakukan riset tentang kepuasan nasabah secara periodik, dan melakukan program pengembangan loyalitas nasabah. 


\section{ABSTRACT}

Measuring service quality and the effect of service quality itself on customer loyalty at Bank Nusa. The customer segments studied were time deposits, savings and current accounts, because at present there are many offers from competing banks that offer similar products and how far the customer can make their choice. The research was conducted using a survey method, with the aim of knowing the responses or opinions of part of the population concerned with the object of research. This research is expected to serve as a basis and evaluation material for Bank Nusa Nasional in order to increase customer loyalty through service quality. Respondents' responses to the service quality of BNN Bank which include tangibles, empathy, reliability, responsiveness, and assurances generally get relatively good ratings from their customers. The level of conformity between customer expectations and the overall service quality of $B N N$ Bank is relatively high. Meanwhile, customer loyalty tends not to be too high. From the results of statistical testing, it turns out that the service quality of BNN Bank has a high enough effect on the loyalty of its customers. In an effort to increase customer loyalty through the quality of the Bank's service, the Nusa Nasional Bank Bandung Branch needs to maintain and improve the quality of its services, including by expanding the service network by increasing the skills of customer service officers, conducting periodic research on customer satisfaction, and conducting customer loyalty development programs.

\section{PENDAHULUAN}

\section{Latar Belakang}

Dewasa ini dalam situasi perbankan nasional yang tidak menentu akibat adanya krisis moneter yang berkepanjangan mengakibatkan adanya perubahan dalam tatanan bidang politik, sosial budaya dan perekonomian yang mana salah satunya akan berdampak negatif terhadap sektor perbankan, diantaranya mengakibatkan meningkatnya suku bunga perbankan yang sangat tinggi dan tidak dapat diantisipasi dengan keadaan perekonomian yang normal. Kenaikan suku bunga perbankan terjadi pada kenaikan bunga pinjaman yang tidak terkendali dari sekitar $20 \%$ p.a sampai bulan Juli 1997 menjadi sekitar 40 s/d 50\% p.a pada bulan Oktober 1998 dan bunga deposito naik tajam dari sekitar 6-17\% p.a sampai bulan Juli 1997 naik tertinggi sampai 72,5 $\%$ pada bulan September 1998 disertai pula dengan bunga tabungan dan giro, hal ini tidak dapat ditelorir lagi sebagai akibat dari krisis perekonomian yang berkepanjangan.

Tingkat pengetahuan dan pendidikan masyarakat Indonesia yang relatif cukup tinggi mengakibatkan nasabah cenderung untuk memilih Bank sesuai dengan apa yang diketahuinya melalui media cetak, TV dan alat komunikasi lain serta dengan didukungnya Pengumuman pemerintah terhadap 16 Bank Likuidasi pada bulan November 1997 dan tujuh Bank Beku Operasi pada bulan April 1998 membuat nasabah 
mengerti apa yang harus diperbuat kepada Bank sesuai dengan pilihannya. Keadaan tersebut membuat efek kurang baik terhadap perbankan nasional, khususnya perbankan swasta yang rentan isu rush yang dapat merugikannya seperti banyak di alami oleh Bank-Bank Papan atas menghadapi ketidakpastian pemerintah dalam menangani perbankan nasional (khususnya Swasta) banyak Bank-bank swasta meningkatkan kewaspadaan terhadap gejala yang mungkin timbul sebagai akibat berubahnya persepsi nasabah terhadap Bank swasta.

Keadaan perbankan Nasional menjadi semakin kompetitif, apalagi setelah adanya era deregulasi semua Bank berlomba meningkatkan asetnya untuk memenangkan persaingan. Bagaimana dahsyatnya persaingan antar Bank setelah Pakto 27, digambarkan oleh seseorang dengan kata-kata sebagai berikut : Dunia Perbankan di tanah air kini berada dalam suatu sistem "perang total". Bank-bank berebut dana masyarakat, berlomba mendirikan kantor cabang dan perang antar Bank bukan terjadi antara Bank lama dengan Bank baru, tetapi juga antar Bank Pemerintah, Bank-bank Swasta dan Bank asing.

Di samping itu masih dalam rangka peningkatan kualitas pelayanan dan persaingan, unsur manusia merupakan hal yang fundamental dalam pemasaran jasa perbankan. Penempatan tenaga-tenaga profesional perbankan diharapkan dapat memberi kekuatan bank untuk memasuki gelanggang persaingan. Harapan tersebut mengakibatkan adanya pembajakan tenaga-tenaga profesional antar bank. Selanjutnya pelayanan pribadi merupakan pula alat yang digunakan dalam persaingan. Beberapa bank telah memperkenalkan tele Banking, dengan perantaraan pesawat telepon nasabah dapat melakukan pembayaran listrik, pajak sampai pada transfer melalui Bank tersebut.

Spesialisasi nampaknya telah digunakan sebagai alat persaingan, ada Bank yang mengkhususkan diri dalam membiayai bidang industri, bidang konstruksi, bidang konsumen dan lainnya, walaupun dalam keadaan sekarang Bank-bank tidak dapat memberikan kredit kepada debitur sesuai dengan peraturan pemerintah. Untuk memaksimalkan pelayanan kepada para nasabah perlu adanya beberapa faktor kunci dalam memberikan pelayanan kepada nasabah, menurut Jeffrey M. Margolies mengemukakan empat faktor kunci yang dituangkan dalam artikelnya "Good service makes excellent companies" sebagai berikut :

a) Di samping kualitas produk, pelayanan adalah faktor kunci untuk mencapai profitabilitas.

b) Pelayanan yang baik merupakan nilai tambah untuk nasabah. Nasabah membutuhkan informasi, karena itu merupakan tugas bagi perbankan untuk memberikan informasi yang relevan kepada mereka dan di samping itu juga membantu dalam mengambil keputusan.

c) Pelayanan menyangkut hubungan dengan manusia lain, oleh karena itu diperlukan cara-cara tertentu yang sering sangat sederhana namun disepelekan (tidak dihargai). Pelayanan adalah suatu time real activity, karena itu orang mengatakan real time berarti real money dan apapun yang dibutuhkan nasabah dilayani dengan baik dan tidak di tunda-tunda. 
d) Perlu adanya sistem pelayanan yang baku dan alat untuk mengukur hasilnya, karena kerja merupakan suatu totalitas, maka setiap proses kerja harus di ukur dengan tingkat efisiensinya. Pertama kali harus dicari lebih dahulu aktivitas yang paling vital dalam pelayanan, seperti keakurasian data atau informasi yang disampaikan kepada nasabah. Hal ini dapat dilakukan apabila di dukung oleh suatu mekanisme yang rasional dan juga kemampuan dari operator Bank.

Keempat kunci pelayanan di atas terkandung pula unsur produk dan manusia yang menurut penilaian penulis merupakan fokusnya/inti, disamping itu terdapat pula unsur-unsur yang menunjang pelayanan antara lain :

a) Organisasi dan manajemen, organisasi yang delegatif dan manajemen yang didesentralisasikan jelas akan mempercepat pelayanan.

b) Sistem dan prosedur, misalnya bank yang menganut sistem loan officer atau account officer dan adanya proses kerja sederhana yang tidak berbelit-belit.

c) Penggunaan pelayanan kantor yang cukup reprensentatif dan modern.

d) Komunikasi antar kantor cabang yang baik (on line system).

e) Lokasi kantor Bank yang mudah dicapai oleh nasabah, kenyamanan ruangan kantor dan peralatan parkir yang memadai merupakan penunjang pelayanan perbankan.

f) Dedikasi karyawan yang tinggi terhadap banknya dan kerjasama yang baik antar karyawan.

\section{LANDASAN TEORI}

\section{Rumusan Masalah}

Berdasarkan uraian pada identifikasi masalah maka dapat diidentifikasi masalah sebagai berikut :

1. Sampai sejauh mana kesesuaian antara harapan nasabah dengan kinerja pelayanan Bank Nusa Nasional Cabang Bandung.

2. Sampai sejauh mana kualitas pelayanan Bank Nusa Nasional Cabang Bandung berpengaruh terhadap loyalitas nasabah.

\section{Tujuan}

Tujuan penelitian ini adalah untuk mengumpulkan data dan informasi, mengolah dan kemudian menganalisis data dan informasi tentang kinerja pelayanan Bank BNN Cabang Bandung dan loyalitas nasabah. Kemudian hasil analisis itu diukur pengaruhnya terhadap loyalitas nasabah di Bank BNN Cabang Bandung.

\section{HASIL DAN PEMBAHASAN}

\section{Pengujian Hipotesis Penelitian}

Hasil penelitian mengenai pengaruh dari kualitas pelayanan Bank BNN Cabang Bandung sebanyak lima buah sub variabel yakni Tangibles (X1), Emphaty (X2), Reliability (X3), Responsiveness (X4), dan Assurances (X5) terhadap loyalitas nasabah (Y), terdiri dari lima hipotesis minor. Adapun Hipotesis mayor yang akan diuji adalah yakni: Semakin tinggi kualitas pelayanan Bank BNN Cabang Bandung maka akan berpengaruh positif terhadap loyalitas nasabah. Sedangkan hipotesis minornya adalah sebagai berikut : 
1. Tangibles berpengaruh positif terhadap loyalitas nasabah Bank BNN Cabang Bandung.

2. Emphaty berpengaruh positif terhadap loyalitas nasabah Bank BNN Cabang Bandung.

3. Reliability berpengaruh positif terhadap loyalitas nasabah Bank BNN Cabang Bandung.

4. Responsiveness berpengaruh positif terhadap loyalitas nasabah Bank BNN Cabang Bandung.

5. Assurances berpengaruh positif terhadap loyalitas nasabah Bank BNN Cabang Bandung.

Pengujian hipotesis ini dilakukan menggunakan analisa jalur dengan langkah-langkah sebagai berikut :

Tabel 2.1. Matriks Korelasi Antara Sub Variabel

\begin{tabular}{lllllll} 
& $\mathrm{X} 1$ & $\mathrm{X} 2$ & $\mathrm{X} 3$ & $\mathrm{X} 4$ & $\mathrm{X} 5$ & $\mathrm{Y}$ \\
$\mathrm{X} 1$ & 1 & 0.8141 & 0.2651 & 0.6951 & 0.7151 & 0.68981 \\
$\mathrm{X} 2$ & 0.8141 & 1 & 0.3026 & 0.7993 & 0.6186 & 0.7099 \\
X3 & 0.2651 & 0.3026 & 1 & 0.4497 & 0.5702 & 0.5134 \\
X4 & 0.6951 & 0.7993 & 0.4497 & 1 & 0.6971 & 0.7512 \\
X5 & 0.7151 & 0.6186 & 0.5702 & 0.6971 & 1 & 0.7169 \\
XY & 0.68981 & 0.7099 & 0.5134 & 0.7512 & 0.7169 & 1 \\
\hline
\end{tabular}

Sumber: Data hasil olahan

Sedangkan matriks invers korelasinya adalah :

Tabel 2.2. Matriks Invers Korelasi

\begin{tabular}{lccccc} 
& $\mathrm{X} 1$ & $\mathrm{X} 2$ & $\mathrm{X} 3$ & $\mathrm{X} 4$ & $\mathrm{X} 5$ \\
$\mathrm{X} 1$ & 4.07365516 & -2.495407 & 0.66323 & 0.161402 & -1860099 \\
$\mathrm{X} 2$ & -2.49540731 & 4.449638 & -0.024502 & -2.229173 & 0.599847 \\
$\mathrm{X} 3$ & 0.663230325 & -0.024502 & 1.651377 & -0.403849 & -1.119211 \\
X4 & 0.161401556 & -2.229173 & -0.403849 & 3.520765 & -0.960502 \\
X5 & -1.860098801 & 0.599847 & -1.119211 & -0.960502 & 3.266831 \\
\hline
\end{tabular}

Sumber: Data hasil olahan

Koefisien jalur ditentukan melalui perumusan

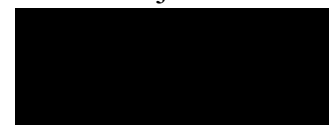

$\mathrm{I}=1,2, \ldots, 5$

melalui:

Sedangkan pengaruh variabel lainnya di luar variabel $\mathrm{X}_{1}$ sampai $\mathrm{X}_{5}$ ditentukan

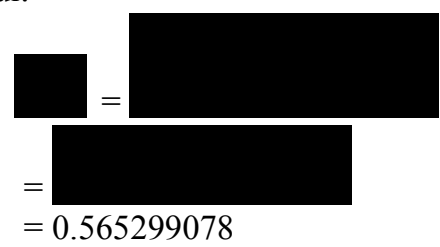

88 | Tambunan, Dennis Rydarto; Pengaruh Kualitas Pelayanan Bank Nusa...... 
Didasarkan pada kerangka teori bahwa ada pengaruh positif antara service quality terhadap loyalitas akan diuji hipotesis secara keseluruhan tersebut dengan bentuk sebagai berikut

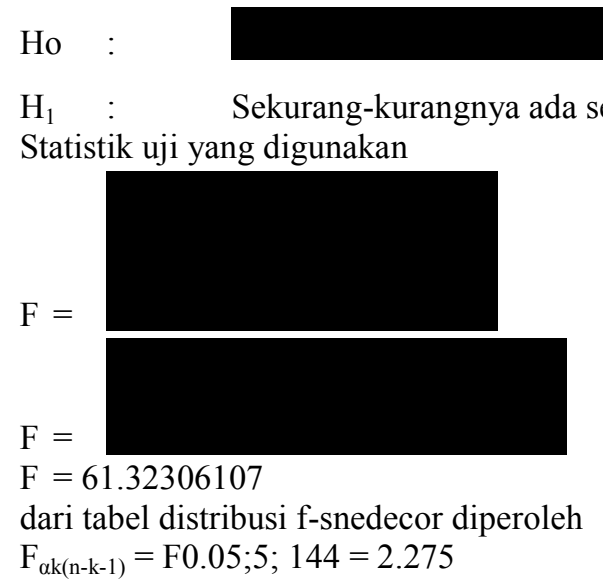

Karena $\mathrm{F}>\mathrm{F}_{\alpha ; \mathrm{k}(\mathrm{n}-\mathrm{k}-\mathrm{l})}$, maka Ho ditolak, berarti dapat diteruskan pada pengujian individu dengan hipotesis sebagai berikut:

$$
\begin{array}{lll}
\mathrm{Ho} & : & \mathrm{p}_{\mathrm{Yxi}} \leq 0 \\
\mathrm{H}_{1} & : & \mathrm{p}_{\mathrm{Yxi}}>0
\end{array}
$$

Dan statistik uji yang digunakan adalah :

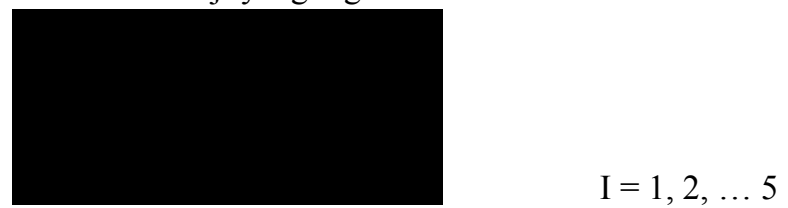

\begin{tabular}{|c|c|c|c|c|c|}
\hline No & Hipotesis & $\begin{array}{l}\text { Koef. } \\
\text { Jalur }\end{array}$ & T Hitung & $\begin{array}{c}\mathbf{T} \\
\text { Tabel }\end{array}$ & Kesimpulan Statistik \\
\hline 1 & $\begin{array}{l}\text { Service Quality } \\
\text { mempunyai } \\
\text { pengaruh positif } \\
\text { terhadap loyalitas }\end{array}$ & $\begin{array}{c}0.1668 \\
00866\end{array}$ & 1.75432152 & 1.65 & $\begin{array}{l}\text { Ho ditolak } \\
\text { Terdapat pengaruh yang nyata } \\
\text { antara X1 dan } \mathrm{Y}\end{array}$ \\
\hline 2 & & $\begin{array}{c}0.1803 \\
37501\end{array}$ & 1.81479131 & 1.65 & $\begin{array}{l}\text { Ho ditolak } \\
\text { Terdapat pengaruh yang nyata } \\
\text { antara } \mathrm{X} 2 \text { dan } \mathrm{Y}\end{array}$ \\
\hline 3 & & $\begin{array}{l}0.1821 \\
92055\end{array}$ & 3.00960347 & 1.364 & $\begin{array}{l}\text { Ho ditolak } \\
\text { Terdapat pengaruh yang nyata } \\
\text { antara X3 dan } Y\end{array}$ \\
\hline 4 & & $\begin{array}{l}0.2777 \\
24828\end{array}$ & 3.14194932 & 1.65 & $\begin{array}{l}\text { Ho ditolak terdapat pengaruh } \\
\text { yang nyata antara } \mathrm{X} 45 \text { dan } \mathrm{Y}\end{array}$ \\
\hline 5 & & $\begin{array}{l}0.1885 \\
76021\end{array}$ & 2.21475699 & 1.65 & $\begin{array}{l}\text { Ho ditolak terdapat pengaruh } \\
\text { yang nyata antara } \mathrm{X} 5 \text { dan } \mathrm{Y}\end{array}$ \\
\hline
\end{tabular}

Tabel 2.3. Pengujian Hipotesis Minor 
Harga-harga $t_{1}$ sampai dengan $t_{5}$ jatuh di daerah Ho ditolak, artinya koefisien jalur signifikan dan diagram jalur tidak mengalami perubahan.

Selanjutnya akan diuji keberartian koefisien korelasi antar variabel Xi sampai dengan X5 dengan hipotesis sebagai berikut:

$$
\begin{array}{ll}
\text { Ho } & : p_{\text {xixj }}=0 \\
\text { H1 } & : p_{\text {xixj }} \neq 0
\end{array}
$$

Dengan statistik uji sebagai berikut :

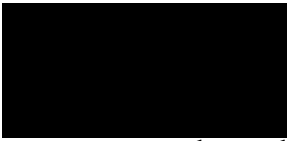

dengan menggunakan tabel distribusi t diperoleh

$\mathrm{t}_{(\mathrm{f}-\alpha / 2 ; \mathrm{n}-\mathrm{k}-1)}=\mathrm{t}_{(1-0.05 / 2 ; 144)}=1-97$

\begin{tabular}{|c|c|c|c|c|c|}
\hline No & Hipotesis & $\begin{array}{c}\text { Koef. } \\
\text { Korelasi }\end{array}$ & T hitung & T tabel & Kesimpulan Statistik \\
\hline 1 & $\begin{array}{l}\text { Terdapat hubungan } \\
\text { yang berarti antara } \\
\text { xl dan x2 }\end{array}$ & 0.6951 & 11.6025156 & 1.97 & $\begin{array}{l}\text { Ho ditolak } \\
\text { terdapat hubungan yang } \\
\text { nyata antara X1 dan X2 }\end{array}$ \\
\hline 2 & $\begin{array}{l}\text { Terdapat hubungan } \\
\text { yang berarti antara } \\
\text { x1 dan x3 }\end{array}$ & 0.7151 & 12.2760055 & 1.97 & $\begin{array}{l}\text { Ho ditolak } \\
\text { terdapat hubungan yang } \\
\text { nyata antara } \mathrm{x} 1 \text { dan } \mathrm{x} 3\end{array}$ \\
\hline 3 & $\begin{array}{l}\text { Terdapat hubungan } \\
\text { yang berarti antara } \\
\text { x1 dan x4 }\end{array}$ & 0.8141 & 16.8224286 & 1.97 & $\begin{array}{l}\text { Ho ditolak } \\
\text { terdapat hubungan yang } \\
\text { nyata antara } \mathrm{x} 1 \text { dan } \mathrm{x} 4\end{array}$ \\
\hline 4 & $\begin{array}{l}\text { Terdapat hubungan } \\
\text { yang berarti antara } \\
\text { x } 1 \text { dan x } 5\end{array}$ & 0.2651 & 3.2992439 & 1.97 & $\begin{array}{l}\text { Ho ditolak } \\
\text { terdapat hubungan yang } \\
\text { nyata antara } \times 1 \text { dan } \times 5\end{array}$ \\
\hline 5 & $\begin{array}{l}\text { Terdapat hubungan } \\
\text { yang berarti antara } \\
\text { x2 dan x3 }\end{array}$ & 0.6971 & 11.6673701 & 1.97 & $\begin{array}{l}\text { Ho ditolak } \\
\text { terdapat hubungan yang } \\
\text { nyata antara } \times 2 \text { dan } \times 3\end{array}$ \\
\hline 6 & $\begin{array}{l}\text { Terdapat hubungan } \\
\text { yang berarti antara } \\
\text { x2 dan x4 }\end{array}$ & 0.7993 & 15.9612016 & 1.97 & $\begin{array}{l}\text { Ho ditolak } \\
\text { terdapat hubungan yang } \\
\text { nyata antara } \mathrm{x} 2 \text { dan } \mathrm{x} 4\end{array}$ \\
\hline 7 & $\begin{array}{l}\text { Terdapat hubungan } \\
\text { yang berarti antara } \\
\times 2 \text { dan x } 5\end{array}$ & 0.4497 & 6.04178557 & 1.97 & $\begin{array}{l}\text { Ho ditolak } \\
\text { terdapat hubungan yang } \\
\text { nyata antara } \mathrm{x} 2 \text { dan } \times 5\end{array}$ \\
\hline 8 & $\begin{array}{l}\text { Terdapat hubungan } \\
\text { yang berarti antara } \\
\text { x3 dan x4 }\end{array}$ & 0.6186 & 9.44780779 & 1.97 & $\begin{array}{l}\text { Ho ditolak } \\
\text { terdapat hubungan yang } \\
\text { nyata antara } \mathrm{x} 3 \text { dan } \times 4\end{array}$ \\
\hline 9 & $\begin{array}{l}\text { Terdapat hubungan } \\
\text { yang berarti antara } \\
\text { x3 dan x } 5\end{array}$ & 0.5702 & 8.32909407 & 1.97 & $\begin{array}{l}\text { Ho ditolak } \\
\text { terdapat hubungan yang } \\
\text { nyata antara } \times 3 \text { dan x } 5\end{array}$ \\
\hline $\begin{array}{l}1 \\
0\end{array}$ & $\begin{array}{l}\text { Terdapat hubungan } \\
\text { yang berarti antara } \\
\text { x4 dan x } 5\end{array}$ & 0.3026 & 3.80981302 & 1.97 & $\begin{array}{l}\text { Ho ditolak } \\
\text { terdapat hubungan yang } \\
\text { nyata antara } \mathrm{x} 4 \text { dan } \times 5\end{array}$ \\
\hline
\end{tabular}

Tabel 2.4. Pengujian Hubungan Kausal antar variabel

90 | Tambunan, Dennis Rydarto; Pengaruh Kualitas Pelayanan Bank Nusa...... 
Pengujian signifikan. Artinya terdapat hubungan antar variabel-variabel tersebut. Secara lengkap struktural kausal antara variabel $\mathrm{X}_{1}, \mathrm{X}_{2}, \mathrm{X}_{3}, \mathrm{X}_{4}, \mathrm{X}_{5}$, dan $\mathrm{Y}$ dapat diungkapkan pada gambar dibawah ini.

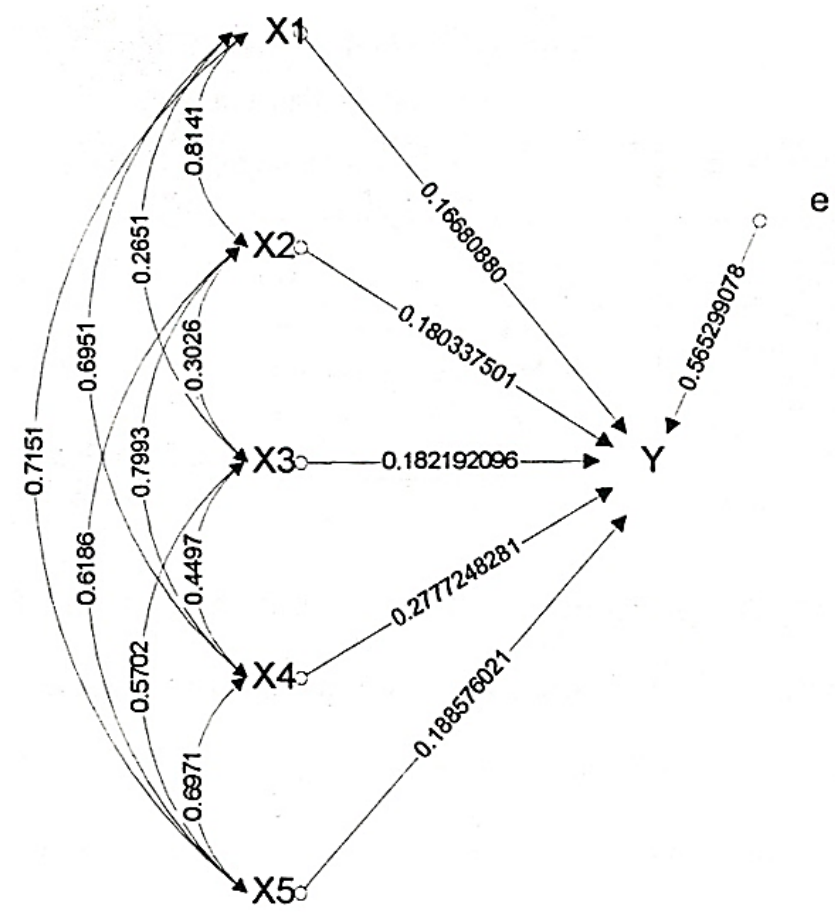

Gambar 2. 1. Hubungan Kausal Antara $X_{1}, X_{2}, X_{3}, X_{4}, X_{5}$ dan $Y$

Dari gambar struktural hubungan kausal antar variabel dengan nilai- nilai parameter struktur diatas, maka pengaruh dari variabel penyebab ke variabel akibat, baik yang bersifat langsung maupun tidak langsung dapat ditentukan sebagai berikut:

Tabel 2. 5. Pengaruh Langsung dan Tidak Langsung dari Dimensi Tangibles Terhadap Loyalitas Nasabah

\begin{tabular}{|c|c|c|}
\hline \multicolumn{2}{|c|}{ Pengaruh langsung dan Tidak Langsung dari X1 } & $\begin{array}{c}\text { Besarnya } \\
\text { Kontribusi \% }\end{array}$ \\
\hline $\mathrm{X} 1$ & $\mathrm{P}_{\mathrm{Y}(\mathrm{X} 1)}$ & 2.782254 \\
\hline Melalui X2 & $\mathrm{P}_{\mathrm{Y}(\mathrm{X} 1 \mathrm{X} 2)}=\mathrm{P}_{\mathrm{YX} 1} \mathrm{r}_{\mathrm{X} 1 \mathrm{X} 2} \mathrm{P}_{\mathrm{YX} 2}$ & 2.44885 \\
\hline Melalui X3 & $\mathrm{P}_{\mathrm{Y}(\mathrm{X} 1 \mathrm{X} 3)}=\mathrm{P}_{\mathrm{YX} 1} \mathrm{r}_{\mathrm{X} 1 \mathrm{X} 3} \mathrm{P}_{\mathrm{YX} 3}$ & 0.805633 \\
\hline Melalui X4 & $\mathrm{P}_{\mathrm{Y}(\mathrm{X} 1 \mathrm{X} 4)}=\mathrm{P}_{\mathrm{YX} 1} \mathrm{r}_{\mathrm{X} 1 \mathrm{X} 4} \mathrm{P}_{\mathrm{YX} 4}$ & 3.220033 \\
\hline Melalui X5 & $\mathrm{P}_{\mathrm{Y}(\mathrm{X} 1 \mathrm{X} 5)}=\mathrm{P}_{\mathrm{YX} 1} \mathrm{r}_{\mathrm{X} 1 \mathrm{X} 5} \mathrm{P}_{\mathrm{YX} 5}$ & 2.249322 \\
\hline \multicolumn{2}{|c|}{ Total Pengaruh dari X1 terhadap Y } & 11.50609 \\
\hline
\end{tabular}

Sumber: Data hasil olahan

Dari tabel di atas dapat terlihat bahwa pengaruh langsung dari penyediaan pelayanan dalam bentuk fisik Bank BNN (Tangibles) terhadap loyalitas nasabah relatif kecil yakni sebesar 2.78\%. Pengaruh tidak langsung terbesar adalah dari X1 melalui sub variabel Responsibility (X4) sebesar 3,22\%. Total pengaruh penyediaan pelayanan dalam bentuk fisik Bank BNN (Tangibles) terhadap loyalitas nasabah yakni sebesar $11,50 \%$, hal ini dapat memberikan gambaran bahwa Tangibles relatif berpengaruh kecil terhadap loyalitas nasabah. 
Tabel 2.6. Pengaruh Langsung dan Tidak Langsung dari Dimensi Emphaty Terhadap Loyalitas Nasabah

\begin{tabular}{|l|c|c|}
\hline \multicolumn{2}{|c|}{ Pengaruh langsung dan Tidak Langsung dari X2 } & $\begin{array}{c}\text { Besarnya } \\
\text { kontribusi \% }\end{array}$ \\
\hline $\mathrm{X} 2$ & $\mathrm{P}_{\mathrm{Y}(\mathrm{X} 2)}$ & 3.252161 \\
\hline Melalui X1 & $\mathrm{P}_{\mathrm{Y}(\mathrm{X} 2 \mathrm{X} 2)}=\mathrm{P}_{\mathrm{YX} 2} \mathrm{r}_{\mathrm{X} 1 \mathrm{X} 2} \mathrm{P}_{\mathrm{YX} 2}$ & 2.44885 \\
\hline Melalui X3 & $\mathrm{P}_{\mathrm{Y}(\mathrm{X} 2 \mathrm{X} 3)}=\mathrm{P}_{\mathrm{YX} 2} \mathrm{r}_{\mathrm{X} 2 \mathrm{X} 3} \mathrm{P}_{\mathrm{YX} 3}$ & 0.994224 \\
\hline Melalui X4 & $\mathrm{P}_{\mathrm{Y}(\mathrm{X} 2 \mathrm{X} 4)}=\mathrm{P}_{\mathrm{Y} 22} \mathrm{r}_{\mathrm{X} 2 \mathrm{X} 4} \mathrm{P}_{\mathrm{YX} 4}$ & 4.00323 \\
\hline Melalui X5 & $\mathrm{P}_{\mathrm{Y}(\mathrm{X} 2 \mathrm{X} 5)}=\mathrm{P}_{\mathrm{YX} 2} \mathrm{r}_{\mathrm{X} 2 \mathrm{X} 5} \mathrm{P}_{\mathrm{YX} 5}$ & 2.103693 \\
\hline \multicolumn{2}{|c|}{ Total Pengaruh dari X2 terhadap Y } & 12.80216 \\
\hline
\end{tabular}

Sumber: Data hasil olahan

Dari tabel di atas dapat terlihat bahwa pengaruh langsung mengenai sikap yang simpatik dan komunikatif karyawan Bank BNN (Emphaty) terhadap loyalitas nasabah relatif kecil yakni sebesar 3,25\%. Pengaruh tidak langsung terbesar adalah dari X1 melalui sub variabel Responsibility (X4) sebesar 4,00\%. Total pengaruh tentang sikap yang simpatik dan komunikatif karyawan Bank BNN (Emphaty) terhadap loyalitas nasabah yakni sebesar 12,80\%, hal ini dapat memberikan gambaran bahwa Emphaty relatif berpengaruh kecil terhadap loyalitas nasabah.

Tabel 2.7. Pengaruh Langsung dan Tidak Langsung dari Dimensi Reliability Terhadap Loyalitas Nasabah

\begin{tabular}{|l|c|c|}
\hline \multicolumn{2}{|c|}{ Pengaruh langsung dan Tidak Langsung dari $\mathrm{X} 3$} & $\begin{array}{c}\text { Besarnya } \\
\text { Kontribusi \% }\end{array}$ \\
\hline $\mathrm{X} 3$ & $\mathrm{P}_{\mathrm{Y}(\mathrm{X} 3)}$ & 3.319394 \\
\hline Melalui X1 & $\mathrm{P}_{\mathrm{Y}(\mathrm{X} 3 \mathrm{X} 1)}=\mathrm{P}_{\mathrm{YX} 3} \mathrm{r}_{\mathrm{X} 1 \mathrm{X} 3} \mathrm{P}_{\mathrm{YX} 1}$ & 0.805633 \\
\hline Melalui X2 & $\mathrm{P}_{\mathrm{Y}(\mathrm{X} 2 \mathrm{X} 3)}=\mathrm{P}_{\mathrm{YX} 3} \mathrm{r}_{\mathrm{X} 2{ }_{3} 3} \mathrm{P}_{\mathrm{YX} 2}$ & 2.275449 \\
\hline Melalui X4 & $\mathrm{P}_{\mathrm{Y}(\mathrm{X} 34)}=\mathrm{P}_{\mathrm{YX} 33} \mathrm{r}_{\mathrm{X} 34} \mathrm{P}_{\mathrm{YX} 4}$ & 1.959039 \\
\hline Melalui X5 & $\mathrm{P}_{\mathrm{Y}(\mathrm{X} 3 \mathrm{X} 5)}=\mathrm{P}_{\mathrm{YX} 3} \mathrm{r}_{\mathrm{XX} 35} \mathrm{P}_{\mathrm{YX} 5}$ & 9.35374 \\
\hline \multicolumn{2}{|r|}{ Total Pengaruh dari X3 terhadap $\mathrm{Y}$} & 17.71000 \\
\hline
\end{tabular}

Sumber: Data hasil olahan

Dari tabel di atas dapat terlihat bahwa pengaruh langsung mengenai konsistensi dan keandalan jasa Bank BNN (Reliability) terhadap loyalitas nasabah relatif kecil yakni sebesar $3,32 \%$. Pengaruh tidak langsung terbesar adalah dari X1 melalui sub variabel nsibility (X5) sebesar 9,35\%. Total pengaruh tentang konsistensi dan keandalan jasa Bank BNN (Reliability) terhadap loyalitas nasabah yakni sebesar $17,71 \%$, hal ini dapat memberikan gambaran bahwa Reliability relatif cukup berpengaruh terhadap loyalitas nasabah.

Tabel 2. 8. Pengaruh Langsung dan Tidak Langsung dari Dimensi Responsiveness Terhadap Loyalitas Nasabah

\begin{tabular}{|c|c|c|}
\hline \multicolumn{2}{|c|}{ Pengaruh langsung dan Tidak Langsung dari X4 } & Besarnya Kontribusi \% \\
\hline 4 & $\mathrm{P}_{\mathrm{Y}(\mathrm{X} 4)}$ & 7.713108 \\
\hline Telalui X1 & $\mathrm{Y}(\mathrm{X} 4 \mathrm{X} 1)=\mathrm{P}_{\mathrm{YX} 4} \mathrm{r}_{\mathrm{X} 4 \mathrm{X} 1} \mathrm{P}_{\mathrm{YX} 1}$ & 3.220033 \\
\hline Telalui X2 & $\mathrm{Y}(\mathrm{X} 4 \mathrm{X} 2)=\mathrm{P}_{\mathrm{YX} 4} \mathrm{r}_{\mathrm{X} 4 \mathrm{X} 2} \mathrm{P}_{\mathrm{YX} 2}$ & 4.00323 \\
\hline Telalui X3 & $\mathrm{Y}(\mathrm{X} 4 \mathrm{X} 3)=\mathrm{P}_{\mathrm{YX} 4} \mathrm{r}_{\mathrm{X} 4 \mathrm{X} 3} \mathrm{P}_{\mathrm{YX} 3}$ & 2.275449 \\
\hline Ielalui X5 & $\mathrm{Y}(\mathrm{X} 4 \mathrm{X} 5)=\mathrm{P}_{\mathrm{YX} 4} \mathrm{r}_{\mathrm{X} 4 \mathrm{X} 5} \mathrm{P}_{\mathrm{YX} 5}$ & 3.650869 \\
\hline & X4 terhadap Y & 20.86269 \\
\hline
\end{tabular}

Sumber: Data hasil olahan

92 | Tambunan, Dennis Rydarto; Pengaruh Kualitas Pelayanan Bank Nusa...... 
Dari tabel di atas dapat terlihat bahwa pengaruh langsung mengenai kesigapan dan kecepatan pelayanan petugas Bank BNN (Responsiveness) terhadap loyalitas nasabah sebesar 7,71\%. Pengaruh tidak langsung terbesar adalah dari X1 melalui sub variabel Emphaty (X2) sebesar 4,00\%. Total pengaruh tentang kesigapan dan kecepatan pelayanan petugas Bank BNN (Responsiveness) terhadap loyalitas nasabah yakni sebesar $20,86 \%$, hal ini dapat memberikan gambaran bahwa Responsiveness relatif berpengaruh terhadap loyalitas nasabah Bank BNN.

Tabel 2.9. Pengaruh Langsung dan Tidak Langsung dari Dimensi Assurances Terhadap Loyalitas Nasabah

\begin{tabular}{|c|c|c|}
\hline \multicolumn{2}{|c|}{ Pengaruh langsung dan Tidak Langsung dari X5 } & Besarnya Kontribusi \% \\
\hline X5 & $\mathrm{P}_{\mathrm{Y}(\mathrm{X} 5)}$ & 3.556092 \\
\hline Melalui X1 & $\mathrm{P}_{\mathrm{Y}(\mathrm{X} 5 \mathrm{X} 1)}=\mathrm{P}_{\mathrm{YX} 5} \mathrm{r}_{\mathrm{X} 5 \mathrm{X} 1} \mathrm{P}_{\mathrm{YX} 1}$ & 2.249322 \\
\hline Melalui X2 & $\mathrm{P}_{\mathrm{Y}(\mathrm{X} 5 \mathrm{X} 2)}=\mathrm{P}_{\mathrm{YX} 5} \mathrm{r}_{\mathrm{X} 5 \mathrm{X} 2} \mathrm{P}_{\mathrm{YX} 2}$ & 2.103693 \\
\hline Melalui X3 & $\mathrm{P}_{\mathrm{Y}(\mathrm{X} 5 \mathrm{X} 3)}=\mathrm{P}_{\mathrm{YX} 5} \mathrm{r}_{\mathrm{X} 53} \mathrm{P}_{\mathrm{YX} 3}$ & 1.959039 \\
\hline Melalui X4 & $\mathrm{P}_{\mathrm{Y}(\mathrm{X} 5 \mathrm{X} 4)}=\mathrm{P}_{\mathrm{YX} 5} \mathrm{r}_{\mathrm{X} 5 \mathrm{X} 5} \mathrm{P}_{\mathrm{YX} 4}$ & 3.650869 \\
\hline \multicolumn{3}{|c|}{ Total Pengaruh dari X5 terhadap $\mathrm{Y}$} \\
\hline
\end{tabular}

Sumber: Data hasil olahan

Dari tabel di atas dapat terlihat bahwa pengaruh langsung mengenai keterampilan dan keramahan petugas Bank BNN (Assurances) terhadap loyalitas nasabah sebesar 3,56\%. Pengaruh tidak langsung terbesar adalah dari X1 melalui sub variabel Responsibility (X4)

\section{KESIMPULAN DAN SARAN}

\section{Kesimpulan}

Tanggapan responden terhadap kualitas pelayanan Bank BNN yang meliputi tangibles, emphaty, reliability, responsiveness, dan assurances pada umumnya relatif mendapat penilaian baik dari para nasabahnya. Tingkat kesesuaian antara harapan nasabah dan kualitas pelayanan Bank BNN secara keseluruhan relatif tinggi. Sedangkan Loyalitas nasabah cenderung belum terlalu tinggi. Dari hasil pengujian statistik ternyata bahwa .kualitas pelayanan Bank BNN berpengaruh cukup tinggi terhadap loyalitas para nasabahnya.

1. Tanggapan responden terhadap kualitas pelayanan Bank BNN yang meliputi tangibles, emphaty, reliability, responsiveness, dan assurances pada umumnya relatif mendapat penilaian baik dari para nasabahnya. Hal ini didasarkan atas penghitungan persentasi ratarata dari nilai skor kinerja terhadap total skor untuk kelima sub variabel tersebut yakni mencapai sebesar $79,62 \%$. Kualitas pelayanan tertinggi diperoleh dari pelayanan yang bersifat asurances yakni mencapai $85,49 \%$ dari skor total variabel tersebut, sedangkan kualitas pelayanan terendah diperoleh dari pelayanan tangibles sebesar $74,19 \%$, berada di bawah rata-rata skor total untuk kelima sub variabel.

2. Tingkat kesesuaian antara harapan nasabah dan kualitas pelayanan Bank BNN secara keseluruhan relatif tinggi yakni mencapai tingkat kesesuaian rata-rata untuk kelima sub variabel sebesar $87,90 \%$. Tingkat kesesuaian tertinggi diperoleh dari pelayanan berupa assurances sebesar $91,97 \%$. Rasio tingkat kesesuaian yang berada di bawah rata-rata adalah tentang pelayanan tangibles yaitu sebesar $84,99 \%$.

3. Tingkat loyalitas nasabah terhadap Bank Nusa Nasional Cabang Bandung relatif belum terlalu tinggi, karena mayoritas responden (39,33\%) masih tergolong pada Clients Level dan partners level baru mencapai $22,67 \%$. 
4. Dari hasil pengujian statistik ternyata bahwa kualitas pelayanan Bank BNN berpengaruh cukup tinggi terhadap loyalitas para nasabahnya.

Pengaruh langsung tertinggi berasal dari kualitas pelayanan dalam bentuk responsiveness dan pengaruh terendah adalah dari pelayanan tangibles, pengaruh tidak langsung tertinggi adalah dari responsiveness melalui assurances.

\section{Saran}

Agar kualitas pelayanan Bank Nusa Nasional Cabang Bandung mampu memberikan konstribusi yang lebih tinggi lagi terhadap loyalitas nasabah maka sebaiknya Bank BNN mempertimbangkan hal-hal sebagai berikut :

1. Bank BNN Cabang Bandung perlu mempertahankan dan meningkatkan kualitas pelayanannya dengan jalan sebagai berikut :

$\square$ Perlu memperluas sarana halaman parkir yang selama ini dinilai nasabah masih kurang memadai.

$\square$ Memperluas jaringan ATM, terutama ditempat-tempat yang strategis, seperti di lokasi pusat pembelanjaan.

$\square$ Dirasakan perlu untuk memperluas jaringan pelayanan untuk penarikan dan penyetoran dana yang dapat dilakukan melalui pembukaan Cabang-cabang Kas pembantu.

$\square$ Bank BNN Perlu meningkatkan keterampilan customer services dalam melayani nasabah, karena selama ini masih belum sesuai dengan harapan nasabah.

2. Sehubungan dengan tingkat loyalitas nasabah terhadap Bank Nusa Nasional belum terlalu tinggi, maka sebaiknya Bank BNN mempertimbangkan untuk segera melakukan program pengembangan loyalitas nasabah melalui:

Melakukan riset tentang tingkat kepuasan nasabah

$\square$ Menginventarisir pengalaman nasabah yang telah merasa puas atas pelayanan Bank BNN.

$\square$ Memberikan imbalan kepada nasabah yang telah menciptakan prospek melalui kegiatan pemberian saran kepada pihak lain untuk melakukan penyimpanan dana di Bank BNN Cabang Bandung.

\section{DAFTAR PUSTAKA}

Bateson John E.G., Managing Services Marketing, Second Edition, Dryden Press, Orlando, 1991.

Berkowictz, Eric N, 1996, Essential Of Health Care Marketing, Aspen Publisher lnc., Geetherburg Maryland, USA.

Berry Leonard L. and Parasuraman A., Marketing Services, Macmillan Inc., Englinton Avenue East, New York, 1991.

Griffin, Jill. 1995. Customer Loyalty: How To Keep It, How To Earn It, New York : Lexington Books.

Hague Paul, 1995, Merancang Kuesioner, Bandung : PT. Pustaka Binaman Presindo

Hill, Nigel, 1996, Handbook Of Customer Satisfaction Measurement, Cambridge: Great Britain at the University Press.

J. Supranto, 1997, Pengukuran Tingkat Kepuasan Pelanggan, Jakarta: Rineka Cipta.

Kasmir, SE.,MM, 1998, Bank dan Lembaga Keuangan Lainnya, Jakarta : Raja Grafindo Persada.

94 | Tambunan, Dennis Rydarto; Pengaruh Kualitas Pelayanan Bank Nusa...... 
Kotler, Philip, 1997 Marketing Management: Analysis, Planning, Implementation, and Control, Sevent Edition, Prentice Hall International, Inc. A Division of Simon \& Scuster, Englewood Cliffs, Nj07632.

, Principles at Marketing, Third Edition, New Jersey Prentice Hall. A Division of Simon \& Scuster, Inc., 1994.

Milind Lele, M. 1995, Pelanggan Kunci Keberhasilan, Jakarta:Mitra Utama.

Nazir, Moch. 1988. Metode Penelitian. Jakarta : Ghalia Indonesia.

Oliver, Richard L. 1997, Satisfaction, A Behavioral Perspective On The Consumer, Toronto, Vanderbilt University, The McGrow-Hill Companies, Inc.

Robinson, Paerce. 1997. Manajemen Strategik, Jakarta: Binarupa Aksara

Settle, Aldreck, 1995, The Survey Research Handbook, Maryland, Perdue School of Business Salisbury State University.

Sitepu Nirwana, 1994, Analisis Jalur, Bandung : UPT Jurusan Statistik, FMIPA UNPAD

Stanton, William J. \& Charles Futrell. 1994. Fundamental Of Marketing 8th edition. Singapore : McGrow Hill.

Sucherly, 1996, Strategi Pemasaran Dalam Persaingan Industri Kayu Gergajian Dan Pengaruhnya Terhadap Penjualan, Disertasi Unpad, Bandung.

Siat, Jennie, 1997, Relationship Marketing, Majalah Swa Sembada, Jakarta : No 03/XXVI/ Juli 1997.

Tjiptono Fandi, 1997, Strategi Pemasaran, Yogyakarta : Andi Offset 